Discussion Paper No. 861

\title{
RECENT TRENDS IN CONSUMPTION IN JAPAN AND THE OTHER GROUP OF SEVEN (G7) COUNTRIES
}

\author{
Charles Yuji Horioka
}

December 2012

The Institute of Social and Economic Research Osaka University

6-1 Mihogaoka, Ibaraki, Osaka 567-0047, Japan 


\title{
Recent Trends in Consumption in Japan and the Other Group of Seven (G7) Countries*
}

\author{
Charles Yuji Horioka** \\ Institute of Social and Economic Research, Osaka University, Ibaraki, Osaka, JAPAN, and \\ National Bureau of Economic Research, Inc., Cambridge, Massachusetts, U.S.A.
}

December 2012

\begin{abstract}
In this paper, we present data on recent trends in private consumption and in possible determinants of private consumption (such as GDP, household incomes, household saving rates, household wealth, and employment conditions) in the Group of Seven (G7) countries and find that there has been significant variability among the G7 countries not only in their private consumption growth rates but also in the determinants of private consumption growth during the 2002-07 period. With respect to Japan, we find that private consumption has been relatively stagnant during the 2002-07 period and that the stagnation of private consumption has been due to the stagnation of household income and of household wealth and the relative stability of the household saving rate.
\end{abstract}

Keywords: Consumption; private consumption; GDP; economic growth; households; saving; wealth; employment conditions; unemployment rates; Group of 7 (G7); Japan.

JEL classification numbers: D12, E21, E60, J64

Forthcoming in the Journal of the Asia Pacific Economy, vol. 18, no. 3 (June 2013).

*This research was conducted as part of the Social Resilience Project 2011 of the Pacific Economic Cooperation Council (PECC) and the Japan Institute of International Affairs (JIIA), and the author is grateful to Dr. Yoko Niimi, Ambassador Yoshiji Nogami, the other participants of the Pacific Economic Cooperation Council (PECC) International Workshop on Social Resilience Project 2011, held on July 12, 2011, at Plaza Hall, Kasumigaseki Building, Tokyo, Japan, and of the Twentieth General Meeting of the Pacific Economic Cooperation Council (PECC): State of the Region, held on September 29, 2011, at the Madison Hotel, Washington, D.C., U.S.A., the Guest Editor Noel Gaston, and an anonymous referee for their helpful comments.

${ }^{* *}$ Contact information: Institute of Social and Economic Research, Osaka University, 6-1, Mihogaoka, Ibaraki, Osaka 567-0047, JAPAN. Telephone: 81-6-6879-8586 or 8574. Facsimile: 81-6-6879-8575. Email: horioka@iser.osaka-u.ac.jp 


\section{Introduction}

The Japanese economy has been in a prolonged recession for most of the past two decades (Japan's so called "Lost Decades"), and private consumption has been stagnant for most of this period along with the other components of GDP. However, as Horioka (2006) shows, the stagnation of public and private investment has been even more pronounced than the stagnation of private consumption.

Even during the relatively prosperous period between the Asian financial crisis of 1997-98 and the global financial crisis of 2008-09, the Japanese economy has been relatively stagnant, with private consumption being no exception. In this paper, we present data on recent trends in private consumption growth in Japan and the other Group of Seven (G7) countries (Canada, France, Germany, Italy, the United Kingdom, and the United States) during the 2002-09 period and explore the reasons for why private consumption was stagnant in Japan compared to the other G7 countries. We compare Japan to the other G7 countries because of their importance in the world economy and because we wanted to compare Japan to countries at a similar stage of economic development and with similar market systems.

This paper is organized as follows: In section 2, we present data on recent trends in private consumption in the G7 countries, and in section 3 , we present data on recent trends in possible determinants of private consumption (such as GDP, household incomes, household saving rates, household wealth, and employment conditions) in the G7 countries in order to shed light on the reasons for differences among the G7 countries in recent trends in private consumption. Section 4 is a brief concluding section that summarizes and makes policy prescriptions.

To preview the main findings of this paper, we find that there has been significant variability among the Group of Seven (G7) countries not only in their private consumption growth rates but also in the determinants of private consumption growth during the 2002-07 period, with the relative importance of GDP growth, household income growth, household saving rates, household wealth, and employment conditions varying from country to country. With respect to Japan, we find that private consumption has been relatively stagnant during the 2002-07 period and that the stagnation of private consumption has been due to the stagnation of household income 
and of household wealth and the relative stability of the household saving rate.

\section{Trends in Private Consumption Growth}

Table 1 shows, among other things, data on the average annual real growth rate of private consumption in the G7 countries during the 2002-07 and 2007-09 periods (with the countries arranged from highest to lowest with respect to growth rates in 2002-07). As can be seen from the table, there were substantial differences among the G7 countries in private consumption growth rates in both periods. During the 2002-07 period, private consumption increased fastest in Canada (3.74 percent) and the United States (2.98 percent), relatively fast in the United Kingdom (2.44 percent) and France (2.09 percent), and slowest in Japan (1.30 percent), Italy (1.05 percent), and Germany (0.33 percent).

During the 2007-09 period, the average annual private consumption growth rate was lower than during the 2002-07 period in all of the G7 countries due to the advent of the global financial crisis, with four of the G7 countries (Italy, Japan, the United Kingdom, and the United States) showing negative private consumption growth rates and only three of the G7 countries (Canada, France, and Italy) showing positive private consumption growth rates. However, the rank ordering of the G7 countries with respect to private consumption growth remained largely unchanged, with Canada still showing the highest average annual private consumption growth rate, France still ranking relative high, and Italy and Japan still ranking relatively low. Germany rises in the rankings, while the United Kingdom and the United States fall in the rankings.

Thus, private consumption growth rates varied considerably among the G7 countries during both time periods, but the differences among the G7 countries were relatively stable.

\section{Determinants of Private Consumption Growth}

In the previous section, we found that there have been substantial and stable differences among the $\mathrm{G} 7$ countries in private consumption growth rates. In this section, we attempt to shed light on the reasons for these substantial differences. However, we confine our analysis to the 2002-07 period for two reasons-first, because sectoral data (in particular, data on the household sector) are still not yet available for 
the most recent period, and second because the 2002-2007 period was a relatively prosperous period between the Asian financial crisis and the global financial crisis and it is important to understand why private consumption growth was relatively stagnant in Japan even during this period of global prosperity.

\section{(1) GDP Growth}

Arguably, the most important determinant of private consumption growth rates is the GDP growth rate. Table 1 shows data on real GDP growth rates alongside data on real private consumption growth rates in the G7 countries during the 2002-07 and 2007-09 periods. As can be seen from this table, there is, in fact, a high correlation between private consumption growth rates and GDP growth rates. Moreover, private consumption growth rates roughly equal GDP growth rates in many countries, including France (2.09 vs. 2.00 percent), Italy (1.05 vs. 1.14 percent), the United Kingdom (2.44 vs. 2.68 percent), and the United States (2.98 vs. 2.75 percent). However, private consumption growth rates exceed GDP growth rates by a considerable margin in some countries such as Canada (3.74 vs. 2.61 percent) and fall short of GDP growth rates by a considerable margin in some countries such as Germany (0.33 vs. 1.55 percent) and Japan (1.30 vs. 2.10 percent) (all figures pertain to the 2002-07 period). Thus, GDP growth rates are apparently not the only determinant of private consumption growth rates.

\section{(2) Household Income Growth}

Another determinant of private consumption growth rates is the growth rate of net household disposable income, and it is quite possible that it is a more important determinant of private consumption growth rates than GDP growth rates because households finance their consumption primarily from net household disposable income. Table 1 shows data on the average annual real growth rate of net household disposable income (deflated by the price deflator for private consumption) in the G7 countries during the 2002-07 period in addition to showing data on the average annual real growth rates of private consumption and GDP during the same time period, and as can

be seen from this table, there is a high correlation between GDP growth rates and household income growth rates, with the two being roughly equal in many countries including France (2.00 vs. 1.94 percent) and the United States (2.75 vs. 2.61 percent). 
However, there are some notable exceptions: the average annual household income growth rate was considerably higher than the average annual GDP growth rate (3.52 vs. 2.61 percent) in Canada during the 2002-07 period, and the fact that the average annual private consumption growth rate was higher than the average annual GDP growth rate in Canada (3.74 vs. 2.61 percent) during the $2002-07$ period can be explained by the fact that the average household income growth rate was higher than the average GDP growth rate in that country during this period.

Conversely, the average annual household income growth rate was considerably lower than the average annual GDP growth rate in Germany ( 0.40 vs. 1.55 percent) and Japan (1.00 vs. 2.10 percent) during the $2002-07$ period, and the fact that the average annual private consumption growth rate was lower than the average annual GDP growth rate in Germany (0.33 vs. 1.56 percent) and Japan (1.30 vs. 2.10 percent) during the 2002-07 period can be explained by the fact that the average annual household income growth rate was lower than the average annual GDP growth rate in these countries during this period. Thus, not surprisingly, household income growth rates appear to be much better at explaining private consumption growth rates than GDP growth rates.

(3) Household Saving Rates

Another possible determinant of consumption growth rates is the household saving rate. Private consumption growth rates will exceed household income growth rates if the household saving rate is declining over time and conversely. In order to shed light on the importance of trends over time in the household saving rate as a determinant of private consumption growth rates, we present data on trends over time in the household saving rate and on the net change in household saving rate in the G7 countries during the 2002-07 period in Table 2 .

As can be seen from this table, the level of the household saving rate varies greatly among the G7 countries, being relatively high in France, Germany, and Italy (8.22 to 13.66 percent), relatively low in Japan, Canada, and the United States (1.48 to 5.09 percent), and negative (-0.05 to -4.27 percent).in the United Kingdom in all years but one (2003, when it was 0.43 percent). More importantly, the G7 countries also show substantial variation in the net change in the household saving rate during the 2002-07 period, with only Germany showing an increase (0.87 percentage points), Canada, 
Japan, France, and the United States showing relatively moderate declines (-0.96, -1.31, and -1.93 percentage points, respectively), and Italy and the United States showing relatively sharp declines (-3.14 and -4.21 percentage points, respectively).

The relatively sharp declines in the household saving rates of Italy and the United Kingdom can explain why private consumption growth rates exceeded household income growth rates in Italy and the United Kingdom (1.05 vs. 0.51 percent in Italy and 2.44 vs. 1.14 percent in the United Kingdom). Thus, trends in household saving rates can explain the divergence between private consumption growth rates and household income growth rates in some cases.

This factor was not so important in Japan because the decline in its household saving rate was not so sharp (-1.31 percentage points), as a result of which its private consumption growth rate was only slightly ( 0.30 percentage points) higher than its household income growth rate during the 2002-07 period. To put it another way, one reason for the stagnation of consumption in Japan during the 2002-07 period is the fact that the household saving rate declined only moderately during this period, due perhaps to increasing precautionary saving brought about by increased pessimism about the future.

\section{(4) Household Wealth}

Private consumption growth will also be influenced by changes in household wealth, with increases (decreases) in household wealth due to capital gains (losses) on equities, land, and other assets causing private consumption to increase (decrease) by more than would be expected by GDP growth, household income growth, and trends in household saving rates.

Table 3 shows data on the ratio of net household wealth to net household disposable income in 2002 and 2007 and the net change in this ratio during the 2002-07 period in the G7 countries. As can be seen from this table, household wealth increased sharply in France (by 235.0 percentage points of household income) and the United Kingdom (by 185.2 percentage points of household income), moderately in Italy (by 109.5 percentage points of household income), the United States (by 101.4 percentage points of household income), and Germany (by 94.0 percentage points of household income), and least sharply in Canada (by 35.8 percentage points of household income) and Japan (by 15.9 
percentage points of household income).

Thus, the sharp increase in household wealth in the United Kingdom (by 185.2 percentage points of net household disposable income) during the 2002-07 period can explain the strong private consumption growth in the U.K. (2.44 percent), and in particular, why the average annual private consumption growth rate during the 2002-07 period was much higher than the average annual household income growth rate during the same period (2.44 vs. 1.14 percent).

By contrast, the stagnation of household wealth in Japan (it increased by only 15.9 percentage points of household disposable income during the 2002-07 period) can explain why private consumption growth was relatively weak during this same period (1.30 percent).

\section{(5) Employment Conditions}

Private consumption growth will also be influenced by employment conditions, with an improvement in (deterioration of) employment conditions leading to higher (lower) private consumption growth than predicted by other factors.

Table 4 shows data on unemployment rates in 2002 and 2007 and the change in the unemployment rate during the 2002-07 period in the G7 countries. As can be seen from this table, employment conditions improved in most G7 countries during the 2002-07 period, with unemployment rates declining by 2.6 percentage points in Italy, 1.7 percentage points in Canada, 1.6 percentage points in Japan, and 1.2 percentage points in the United States, not changing at all in Germany, and increasing by 0.1 percentage points in France and 0.2 percentage points in the United Kingdom during the 2002-07 period.

A comparison of column (3) of Table 1 and column (3) of Table 4 shows that there is little correlation between private consumption growth rates and changes in unemployment rates. The fact that Canada showed the second largest improvement in unemployment rates (1.7 percentage points) as well as the highest growth rate of private consumption (3.74 percent) during the 2002-07 period suggests that there is a positive correlation between the two, but the fact that Italy showed by far the largest improvement in unemployment rates (2.6 percentage points) even though it showed the second lowest 
growth rate of private consumption (1.05 percent), whereas the United Kingdom was one of only two countries showing a deterioration in their unemployment rates (by 0.2 percentage points) even though it showed the third highest growth rate of private consumption ( 2.44 percent) suggests that there is a negative correlation between the two.

Japan ranked third with respect to the improvement in unemployment rates (a decline of 1.6 percentage points) but only fifth with respect to the growth rate of private consumption (1.30 percent), suggesting that the improvement in employment conditions did not do much to boost private consumption growth in Japan.

(6) Conclusion concerning the Determinants of Private Consumption Growth

In this paper, we showed that private consumption growth is determined by trends in GDP growth, household income growth, household saving rates, household wealth, and employment conditions but that the relative importance of these factors differs greatly from country to country.

For example, in the case of Japan, we found that the stagnation of consumption during the 2002-07 period was due to the stagnation of household income (which was much more stagnant than GDP), the stagnation of household wealth, and the relative stability of the household saving rate (which was presumably due in large part to increased pessimism about the future).

Similarly, private consumption was the most stagnant in Germany due primarily to the stagnation of household income (which was much more stagnant than GDP) and due partly to a moderate increase in its household saving rate.

France showed an intermediate growth rate of private consumption because its household income growth rate was also intermediate, but its private consumption growth rate was somewhat higher than its household income growth rate presumably because France showed by far the largest increase in household wealth.

By contrast, the strong growth of private consumption in Canada and the United States was due primarily to the strong growth of household income (far in excess of GDP growth in the case of Canada) and due partly to moderate declines in their household 
saving rates and (in the case of Canada) a sharp improvement in employment conditions.

The most interesting cases are the cases of Italy and the United Kingdom, which showed considerably higher growth rates of private consumption than of household incomes due in large part to the sharp decline in their household saving rates and (especially in the case of the United Kingdom) sharp increases in household wealth.

\section{Summary and Policy Implications}

In this paper, we presented data on recent trends in private consumption and in possible determinants of private consumption (such as GDP, household incomes, household saving rates, household wealth, and employment conditions) in the G7 countries and found that there has been significant variability among the Group of Seven (G7) countries not only in their private consumption growth rates but also in the determinants of private consumption growth during the 2002-07 period, with the relative importance of GDP growth, household income growth, household saving rates, household wealth, and employment conditions varying from country to country.

With respect to Japan, we found that private consumption has been relatively stagnant during the 2002-07 period and that the stagnation of private consumption has been due to the stagnation of household income and of household wealth and the relative stability of the household saving rate.

This suggests that the best way of stimulating private consumption and of bringing about a recovery of the Japanese economy as a whole would be to boost household income and household wealth. However, given that Japan's government debt is already dangerously high (in excess of 200 percent of GDP, making Japan's government debt the highest among the developed countries as a ratio of GDP) and that there is little scope for further monetary easing, it seems that targeted policies would be more realistic and more effective than macroeconomic policies. For example, policies that redistribute income toward the low-income and others with high marginal propensities to consume, such as policies that create more job opportunities and more opportunities for vocational training for young workers (whose unemployment rates are still very 
high) and policies that improve the wages and other benefits and working conditions of part-time and temporary workers (whose share has been increasing), would be effective in boosting private consumption and the economy as a whole.

Finally, since we found that the stability of household saving rates is a contributing factor to the stagnation of private consumption in Japan, improving social safety nets and improving access to consumer credit would also boost private consumption by reducing precautionary saving (see Horioka and Yin (2010) and Horioka and Terada-Hagiwara (2012) for cross-country evidence on the impact of social safety nets and consumer credit on household saving and consumption).

The author hopes that these policy measures will be adopted as soon as possible so that private consumption as well as the Japanese economy as a whole can receive a boost, enabling it to extricate itself from two "lost decades" of stagnant growth and high unemployment. 


\section{References}

Horioka, Charles Yuji (2006), “The Causes of Japan's 'Lost Decade': The Role of Household Consumption," Japan and the World Economy, vol. 18, no. 4 (December), pp. 378-400.

Horioka, Charles Yuji, and Terada-Hagiwara, Akiko (2012), "The Determinants and Long-term Projections of Saving Rates in Developing Asia," Japan and the World Economy, vol. 24, no. 2 (March), forthcoming.

Horioka, Charles Yuji, and Yin, Ting (2010), "Household Savings Rates and Social Benefit Ratios: Country Comparisons," in Masahiro Kawai and Gloria O. Pasadilla, eds., Effects of Social Policy on Domestic Demand: Annual Conference 2009 (Tokyo, Japan: Asian Development Bank Institute (ADBI)), pp. 63-75.

\section{Data Sources}

(For data on consumption, GDP, and net household disposable income)

Organisation for Economic Cooperation and Development (OECD), National Accounts of OECD Countries (Paris, France: Organisation for Economic Cooperation and Development (OECD), 2010), 2010 edition.

(For data on unemployment rates (Annex Table 13), household saving rates (Annex Table 23), and net household wealth to household income ratios (Annex Table 58) Organisation for Economic Cooperation and Development (OECD), OECD Economic Outlook (Paris, France: Organization for Economic Cooperation and Development (OECD)), no. 89 (May 2011). 
Table 1: Growth Rates of GDP, Household Income, and Consumption

\begin{tabular}{|c|c|c|c|c|c|}
\hline & \multicolumn{3}{|c|}{$2002-2007$} & \multicolumn{2}{|c|}{ 2007-2009 } \\
\hline Country & GDP & $\begin{array}{c}\text { Net } \\
\text { Household } \\
\text { Disposable } \\
\text { Income }\end{array}$ & $\begin{array}{c}\text { Private } \\
\text { Consumption }\end{array}$ & GDP & $\begin{array}{c}\text { Private } \\
\text { Consumption }\end{array}$ \\
\hline Canada & 2.61 & 3.52 & 3.74 & -0.98 & 1.67 \\
\hline U.S. & 2.75 & 2.61 & 2.98 & -1.35 & -0.73 \\
\hline U.K. & 2.68 & 1.14 & 2.44 & -2.50 & -1.38 \\
\hline France & 2.00 & 1.94 & 2.09 & -1.41 & 0.21 \\
\hline Japan & 2.10 & 1.00 & 1.30 & -3.76 & -1.33 \\
\hline Italy & 1.14 & 0.51 & 1.05 & -3.29 & -1.30 \\
\hline Germany & 1.55 & 0.40 & 0.33 & -1.91 & 0.27 \\
\hline Mean & 2.12 & 1.59 & 1.99 & -2.17 & -0.37 \\
\hline
\end{tabular}

Table 2: Household Saving Rates

\begin{tabular}{|c|c|c|c|c|c|c|c|}
\hline Country & 2002 & 2003 & 2004 & 2005 & 2006 & 2007 & Change, 2002-07 \\
\hline Canada & 3.53 & 2.70 & 3.24 & 2.18 & 3.63 & 2.57 & -0.96 \\
\hline U.S. & 3.65 & 3.76 & 3.37 & 1.48 & 2.47 & 1.73 & -1.93 \\
\hline U.K. & -0.05 & 0.43 & -1.70 & -1.26 & -2.95 & -4.27 & -4.21 \\
\hline France & 13.66 & 12.46 & 12.36 & 11.37 & 11.44 & 11.87 & -1.79 \\
\hline Japan & 5.09 & 3.88 & 3.63 & 3.85 & 3.65 & 3.78 & -1.31 \\
\hline Italy & 11.36 & 10.34 & 10.30 & 9.96 & 9.19 & 8.22 & -3.14 \\
\hline Germany & 10.06 & 10.41 & 10.55 & 10.63 & 10.71 & 10.92 & 0.87 \\
\hline Mean & 6.76 & 6.28 & 5.96 & 5.46 & 5.45 & 4.97 & -1.78 \\
\hline
\end{tabular}

Table 3: Net Household Wealth to Household Income Ratios

\begin{tabular}{|l|r|r|r|}
\hline \multicolumn{1}{|c|}{ Country } & 2002 & 2007 & Change, 2002-07 \\
\hline Canada & 5.127 & 5.485 & 0.358 \\
\hline U.S. & 5.143 & 6.157 & 1.014 \\
\hline U.K. & 7.156 & 9.008 & 1.852 \\
\hline France & 5.713 & 8.063 & 2.350 \\
\hline Japan & 7.194 & 7.353 & 0.159 \\
\hline Italy & 7.475 & 8.570 & 1.095 \\
\hline Germany & 5.336 & 6.276 & 0.940 \\
\hline Mean & 6.163 & 7.273 & 1.110 \\
\hline
\end{tabular}


Table 4: Unemployment Rates

\begin{tabular}{|c|c|c|c|}
\hline Country & 2002 & 2007 & Change, 2002-07 \\
\hline Canada & 7.7 & 6.0 & -1.7 \\
\hline U.S. & 5.8 & 4.6 & -1.2 \\
\hline U.K. & 5.2 & 5.4 & 0.2 \\
\hline France & 7.9 & 8.0 & 0.1 \\
\hline Japan & 5.4 & 3.8 & -1.6 \\
\hline Italy & 8.7 & 6.1 & -2.6 \\
\hline Germany & 8.3 & 8.3 & 0.0 \\
\hline Mean & 7.0 & 6.0 & -1.0 \\
\hline
\end{tabular}

